\section{Eleutherodactylus coqui (Puerto Rican Frog). Behavior.}

Date of observation: 12 June 2008. Location: Puerto Rico: El yunque; Río Grande. Coordinates: 18.29755, -65.7944. Elevation: 859 m. Voucher: image. This is a report of snail-feeding in Eleutherodactylus coqui. Along Route 191 near Pico El Yunque; at night, we observed a female $E$. coqui trying to swallow a gastropod mollusk (Platysuccinea portoricensis) in the bottom of a ravine and about $20 \mathrm{~m}$ from the road. The frog measured $47.6 \mathrm{~mm} \mathrm{SVL}$, with a mass of $7.2 \mathrm{~g}$. The mollusk's shell measured $18.2 \mathrm{~mm}$ (diameter) by $11.0 \mathrm{~mm}$ (height) and had a mass of $1.5 \mathrm{~g}$. This is the first record of feeding by $E$. coqui on this species of snail. A previous record of snail-feeding by E. coqui involved snails of the genus Caracolus (R. L. Joglar, 1998, Los Coquíes de Puerto Rico, Editorial Universidad de Puerto Rico, p. 40.). Both the frog and the snail were collected and preserved after being photographed. Accompanied by Miguel Acevedo and M. Isabel Herrera (University of Puerto Rico at Río Piedras).

Alberto R. Estrada, Productions eleuth Inc., PMB 25635 JC de Borbon, Ste. 67, Guaynabo, Puerto Rico, 00969, peleuth@gmail.com.
Citation: Estrada AR. 2010. Eleutherodactylus coqui (Puerto Rican Frog). Behavior. Caribbean Herpetology 17:1.

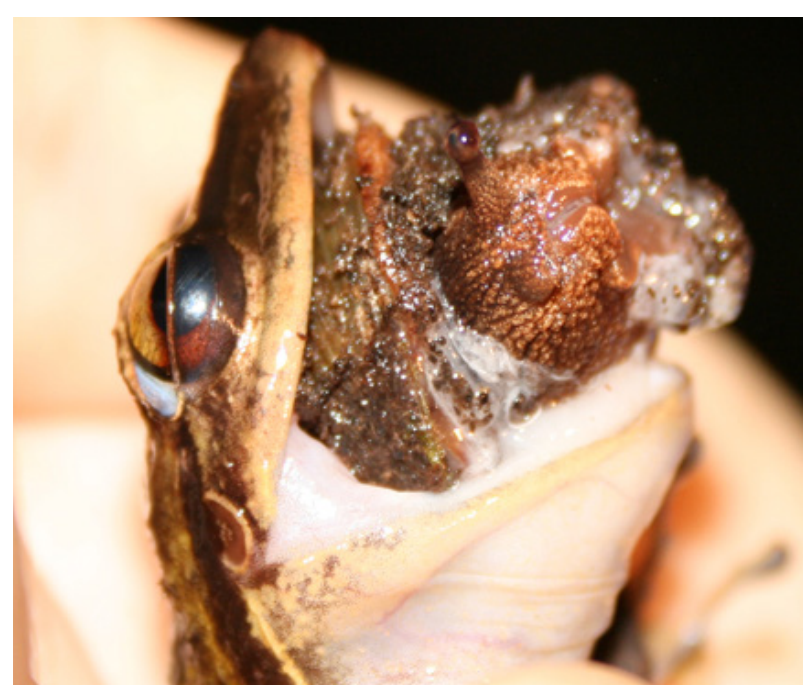

